\title{
EFFECT OF MANGANESE DOPING ON THE MAGNETIC AND MAGNETOCALORIC PROPERTIES OF ZINC FERRITE
}

\author{
VPLIV DOPIRANJA Z Mn NA MAGNETNE IN \\ MAGNETNO-KALORIČNE LASTNOSTI Zn FERITA
}

\author{
Haitao Zhao*, Xuehan Li, Hui Zhao, Yulian Wang \\ School of Materials Science and Engineering, Shenyang Ligong University, Shenyang, China \\ Prejem rokopisa - received: 2019-04-26; sprejem za objavo - accepted for publication: 2019-07-23
}

doi:10.17222/mit.2019.089

\begin{abstract}
$\mathrm{Mn}_{\mathrm{x}} \mathrm{Zn}_{1-\mathrm{x}} \mathrm{Fe}_{2} \mathrm{O}_{4}$ ferrites with $x=0.2,0.4,0.6$ and 0.8 were successfully prepared with the solvothermal method. The structural characteristics, morphology and magnetic properties of the composite powders were obtained with X-ray diffraction (XRD), a scanning electron microscope (SEM) and a vibrating-sample magnetometer (VSM). The results show that $\mathrm{Mn}_{\mathrm{x}} \mathrm{Zn}_{1-\mathrm{x}} \mathrm{Fe}_{2} \mathrm{O}_{4}$ ferrite has a pure cubic spinel structure with a particle size of about 200-300 nm. Ethylene glycol plays an important role during the formation of monodisperse particles. Synthesized particles exhibit ferromagnetic behavior with a small hysteresis at room temperature. Ms reaches the maximum value of $71.99 \mathrm{emu} / \mathrm{g}$ when the amount of manganese ions is $x=0.6$. At $600 \mathrm{~s}$, the temperature of $\mathrm{Mn}_{0.8} \mathrm{Zn}_{0.2} \mathrm{Fe}_{2} \mathrm{O}_{4}$ can rise to $69.9{ }^{\circ} \mathrm{C}$, showing an excellent magnetocaloric effect.

Keywords: zinc ferrite, solvothermal synthesis, magnetic properties, magnetocaloric effect

Avtorji so uspešno sintetizirali $\mathrm{Mn}_{\mathrm{x}} \mathrm{Zn}_{1-\mathrm{x}} \mathrm{Fe}_{2} \mathrm{O}_{4}$ ferite $\mathrm{z} x=0,2,0,4,0,6$ in 0,8 s solvotermalno metodo. Z rentgensko difrakcijo (XRD), vrstično elektronsko mikroskopijo (SEM) in magnetometrom na tresoči se vzorec (VSM), so določili strukturne lastnosti, morfologijo in magnetne lastnosti kompozitnih prahov. Rezultati analiz so pokazali, da ima $\mathrm{Mn}_{\mathrm{x}} \mathrm{Zn}_{1-\mathrm{x}} \mathrm{Fe}_{2} \mathrm{O}_{4}$ ferit čisto kubično-špinelno strukturo z velikostjo delcev okoli $200 \mathrm{~nm}$ do $300 \mathrm{~nm}$. Etilenglikol igra pomembno vlogo pri tvorbi enovite disperzije delcev ferita. Sintetizirani delci imajo feromagnetne lastnosti z majhno histerezo pri sobni temperaturi. Maksimalna vrednost magnetizacije nasičenja $(M \mathrm{~s})$ je bila $71,99 \mathrm{emu} / \mathrm{g}$ pri vsebnosti $\mathrm{Mn}$ ionov $x=0,6$. Po $600 \mathrm{~s}$ temperatura $\mathrm{Mn}_{0.8} \mathrm{Zn}_{0.2} \mathrm{Fe}_{2} \mathrm{O}_{4}$ lahko naraste do $69,9{ }^{\circ} \mathrm{C}$, kar kaže na odličen magnetno-kaloričen učinek.

Ključne besede: cink-ferit, solvotermalna sinteza, magnetne lastnosti, magnetno-kalorično delovanje
\end{abstract}

\section{INTRODUCTION}

MnZn ferrites attracted considerable investigations because of their potential applications in catalysis, magnetic storage, cancer therapy, medical imaging and electronic devices. ${ }^{1-5}$ The chemical processes currently in vogue for the synthesis of MnZn ferrite particles include co-precipitation, ${ }^{6-9}$ the sol-gel auto-combustion method, ${ }^{10-13}$ the solid-state reaction method, ${ }^{14-16}$ solvothermal technique, ${ }^{17-19}$ microwave processing technique, ${ }^{20-22}$ hydrothermal synthesis etc..$^{23-27}$

The solvothermal technique has the advantages of functioning at low temperatures, being a simple, lowcost synthetic process, exhibiting an ease of compositional control and producing ultrafine particles with a narrow-sized distribution. Therefore, the solvothermal technique is an economical and simple strategy for the synthesis of monodisperse powders. G. S. Wang et al. ${ }^{28}$ successfully prepared $\mathrm{ZnFe}_{2} \mathrm{O}_{4}$ nanocrystal clusters with a surfactant-assisted solvothermal method and investigated them as a potential magnetorheological material. W. Shen et al. ${ }^{29}$ demonstrated a simple solvothermal route for the synthesis of monodisperse $\mathrm{Fe}_{3} \mathrm{O}_{4}$ and studied the effects of the reaction parameters on the structure.

*Corresponding author's e-mail: zht95711@163.com (Haitao Zhao)
However, their investigations focused on structural, magnetic and electrical properties at lower frequencies $(<1 \mathrm{GHz})$. Until now, there has been little research work on the magnetic properties and magnetocaloric effect of $\mathrm{MnZn}$ ferrites. In the present study, monodispersed $\mathrm{Mn}_{\mathrm{x}} \mathrm{Zn}_{1-\mathrm{x}} \mathrm{Fe}_{2} \mathrm{O}_{4}(x=0.2,0.4,0.6$ and 0.8$)$ ferrite particles were synthesized using a solvothermal approach. The samples were characterized with various experimental techniques and the properties of ferrite particles were investigated.

\section{EXPERIMENTAL PART}

$\mathrm{Mn}_{\mathrm{x}} \mathrm{Zn}_{1-\mathrm{x}} \mathrm{Fe}_{2} \mathrm{O}_{4}(x=0.2,0.4,0.6$ and 0.8$)$ ferrite particles were synthesized using a solvothermal approach. Analytical-grade $\mathrm{FeCl}_{3} \cdot 6 \mathrm{H}_{2} \mathrm{O}, \mathrm{Zn}\left(\mathrm{NO}_{3}\right)_{2} \cdot 6 \mathrm{H}_{2} \mathrm{O}$ and $\mathrm{MnSO}_{4} \cdot \mathrm{H}_{2} \mathrm{O}$ were used to prepare ferrite powders. The metal salt, weighed according to the stoichiometric proportion, was dissolved evenly in ethylene glycol to obtain a homogeneous solution. After that, the resulting mixture was transferred into a $100-\mathrm{mL}$ Teflon-lined stainless-steel autoclave, and heated to $200{ }^{\circ} \mathrm{C}$ for $12 \mathrm{~h}$. The system was then cooled down to room temperature. The products were obtained with centrifugation, sequentially washed with deionized water and ethanol 
H. ZHAO et al.: EFFECT OF MANGANESE DOPING ON THE MAGNETIC AND MAGNETOCALORIC PROPERTIES ...

for several times and then dried in a vacuum oven at $60{ }^{\circ} \mathrm{C}$ for $12 \mathrm{~h}$.

The phase formation of the synthesized product was identified with X-ray diffraction (XRD, Ultima IV, Rigaku, Japan) using $\mathrm{Cu}-K_{\alpha}$ radiation $(\lambda=0.15418 \mathrm{~nm})$ in a $2 \theta$ range of $20-70^{\circ}$. The morphology of the products was observed with a scanning electron microscope (SEM) on an S-3400N microscope operating at $25 \mathrm{kV}$. Their magnetic properties were measured with a Lake Shore 7410 vibrating-sample magnetometer (VSM) at room temperature.

\section{RESULTS}

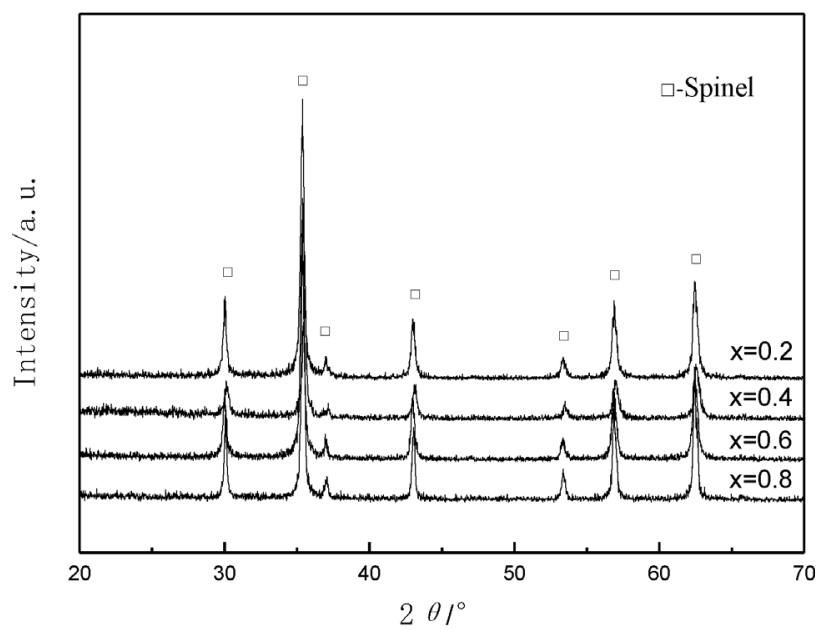

Figure 1: XRD patterns of $\mathrm{Mn}_{\mathrm{x}} \mathrm{Zn}_{1-\mathrm{x}} \mathrm{Fe}_{2} \mathrm{O}_{4}$ ferrites
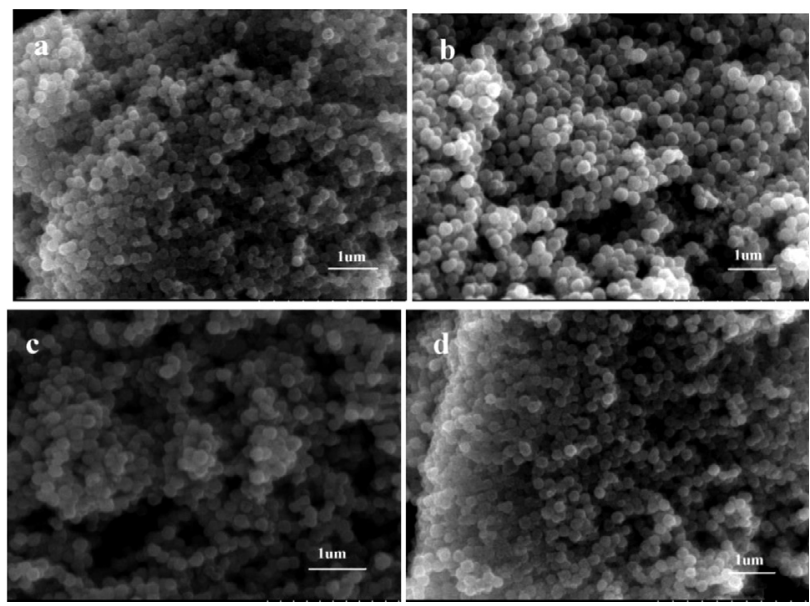

Figure 2: SEM images of $\mathrm{Mn}_{\mathrm{x}} \mathrm{Zn}_{1-\mathrm{x}} \mathrm{Fe}_{2} \mathrm{O}_{4}$ particles: a) $x=0.2$, b) $x=$ 0.4, c) $x=0.6$, d) $x=0.8$
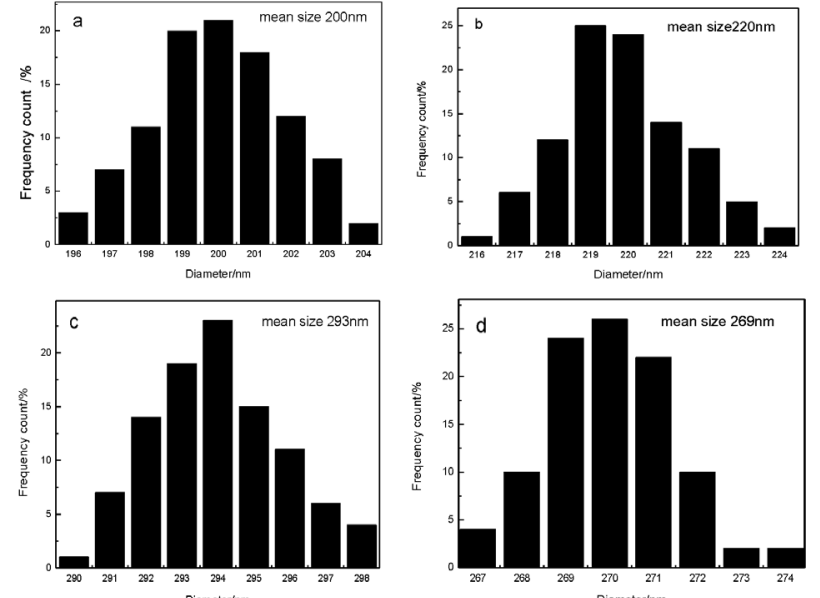

Figure 3: Particle-size distributions of $\mathrm{Mn}_{\mathrm{x}} \mathrm{Zn}_{1-\mathrm{x}} \mathrm{Fe}_{2} \mathrm{O}_{4}$ ferrites: a) $x=$ 0.2 , b) $x=0.4$, c) $x=0.6$, d) $x=0.8$

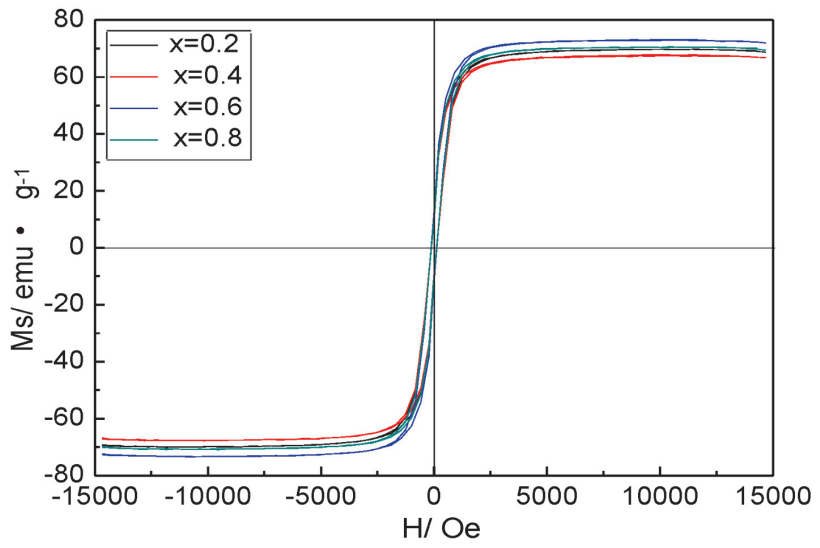

Figure 4: Hysteresis loops of $\mathrm{Mn}_{\mathrm{x}} \mathrm{Zn}_{1-\mathrm{x}} \mathrm{Fe}_{2} \mathrm{O}_{4}$ nanoparticles at room temperature $(300 \mathrm{~K})$

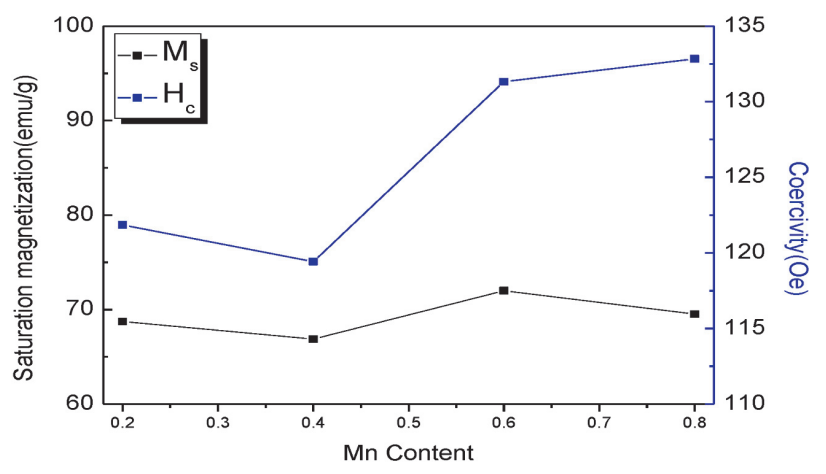

Figure 5: Curves of Mn amounts in Ms and Hc 


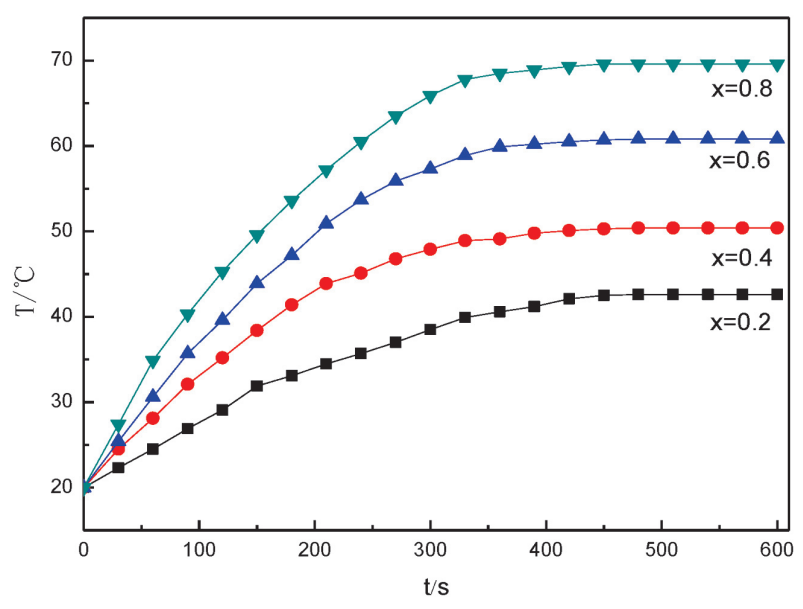

Figure 6: Time-temperature curves of $\mathrm{Mn}_{\mathrm{x}} \mathrm{Zn}_{1-\mathrm{x}} \mathrm{Fe}_{2} \mathrm{O}_{4}$ particles

Table 1: Main magnetic properties of $\mathrm{Mn}_{\mathrm{x}} \mathrm{Zn}_{1-\mathrm{x}} \mathrm{Fe}_{2} \mathrm{O}_{4}$ particles

\begin{tabular}{|c|c|c|c|c|}
\hline Formula & $\begin{array}{c}\mathrm{M}_{\mathrm{s}} \\
(\mathrm{emu} / \mathrm{g})\end{array}$ & $\begin{array}{c}\mathrm{M}_{\mathrm{r}} \\
(\mathrm{emu} / \mathrm{g})\end{array}$ & $\begin{array}{c}\mathrm{H}_{\mathrm{c}} \\
(\mathrm{Oe})\end{array}$ & $\mu_{\mathrm{B}}$ \\
\hline $\mathrm{Mn}_{0.2} \mathrm{Zn}_{0.8} \mathrm{Fe}_{2} \mathrm{O}_{4}$ & 66.87 & 10.35 & 119.42 & 2.88 \\
\hline $\mathrm{Mn}_{0.4} \mathrm{Zn}_{0.6} \mathrm{Fe}_{2} \mathrm{O}_{4}$ & 68.73 & 10.90 & 121.85 & 2.94 \\
\hline $\mathrm{Mn}_{0.6} \mathrm{Zn}_{0.4} \mathrm{Fe}_{2} \mathrm{O}_{4}$ & 71.99 & 12.36 & 131.32 & 3.03 \\
\hline $\mathrm{Mn}_{0.8} \mathrm{Zn}_{0.2} \mathrm{Fe}_{2} \mathrm{O}_{4}$ & 69.53 & 10.30 & 132.84 & 2.91 \\
\hline
\end{tabular}

\section{DISCUSSION}

To identify the phase change, the XRD patterns of $\mathrm{Mn}_{\mathrm{x}} \mathrm{Zn}_{1-\mathrm{x}} \mathrm{Fe}_{2} \mathrm{O}_{4}$ with $x=0.2,0.4,0.6$ and 0.8 are shown in Figure 1. The positions and relative intensities of all diffraction peaks are assigned to the (111), (220), (311), (400), (511), (440) and (533) reflections of those from the JCPDS card (No.73-1963) for $\mathrm{Mn}_{\mathrm{x}} \mathrm{Zn}_{1-\mathrm{x}} \mathrm{Fe}_{2} \mathrm{O}_{4}$. Sharp and strong peaks confirm the obtained powders have a single-phase cubic spinel structure. The average crystal size (D) for each sample is estimated from the diffraction data for the (311) plane from the XRD patterns, in accordance with the Debye-Scherrer formula in Equation (1):

$$
D=\frac{0.89 \lambda}{\beta \cos \theta}
$$

where $\lambda$ is the $\mathrm{X}$-ray wavelength, $\beta$ is the value of the full width at half maximum (FWHM) of the (311) diffraction peak, and $\theta$ is the Bragg angle of the (311) peak. The average crystal size of $\mathrm{Mn}_{\mathrm{x}} \mathrm{Zn}_{1-\mathrm{x}} \mathrm{Fe}_{2} \mathrm{O}_{4}$ ferrites, as deduced from the $\mathrm{X}$-ray data, is in a range of $205 \mathrm{~nm}$ to $287 \mathrm{~nm}$ for all the samples. There is a systematic increase in the crystal size with the increase in the Mn concentration. This phenomenon suggests that the $\mathrm{Mn}^{2+}$ ion doping influences the particle crystallization during the solvothermal process and promotes the grain growth of crystallite $\mathrm{Zn}^{2+}$ owing to crystal-lattice inflations.

SEM images of the $\mathrm{Mn}_{1-\mathrm{x}} \mathrm{Zn}_{\mathrm{x}} \mathrm{Fe}_{2} \mathrm{O}_{4}$ particles are shown in Figure 2. It reveals that the obtained particles demonstrate the high quality and uniformity of the particle size. The particles are monodisperse, exhibiting a spherical shape with a narrow-sized distribution. These particles have an average size of about 200-300 nm. Ethylene glycol plays an important role during the formation of monodisperse particles, which can slow down the aggregation growth of crystals due to fewer surface hydroxyls and a higher viscosity of the system, providing enough time for the powders to rotate adequately, finding a suitable configuration interface.

Particle-size distribution of the $\mathrm{Mn}_{1-\mathrm{x}} \mathrm{Zn}_{\mathrm{x}} \mathrm{Fe}_{2} \mathrm{O}_{4}$ particles is shown in Figure 3. It reveals that the average particle sizes of $x=0.2,0.4,0.6$ and 0.8 are $(200,220$, 293 and 269) nm, respectively. The statistical results are basically consistent with the XRD analysis. In Figure 3a, less than $5 \%$ of the samples is taken up by the total particle sizes of $198 \mathrm{~nm}$ and $204 \mathrm{~nm}$, while (20.05, 22.13 and 18.72) \% of the samples are taken up by the sizes of $(199,200$ and 201) nm, respectively. The combined proportion of the three is $60.90 \%$. In Figure $\mathbf{3 b}$, the proportions of the particles of $219 \mathrm{~nm}$ and 220 $\mathrm{nm}$ are $25.12 \%$ and $23.34 \%$, respectively; both values together amount to $48.46 \%$, while the other-size particles amount to $50 \%$. In Figure 3c, the particles of $291 \mathrm{~nm}$, and $298 \mathrm{~nm}$ account for less than $5 \%$ of the samples, while the particles of $(293,294$ and 295) $\mathrm{nm}$ account for about $60 \%$ of the samples. The particle size of the prepared samples is basically between $293 \mathrm{~nm}$ and $295 \mathrm{~nm}$. It can be concluded that the particle-size distribution of the prepared samples is relatively wide. In Figure 3d, about $73 \%$ of the particles were $(269,270$ and 271) $\mathrm{nm}$. It can be seen that the particle size of the synthesized powders is uniform and the distribution is concentrated when $x=0.8$. As can be seen from Figure 3 , the proportion of the particulate matter can reach about $25 \%$ in some samples, while in other samples, it is less than $5 \%$. The particle spacing is quite different, and the zinc ion content has a certain influence on the particle size of the product. In summary, different stoichiometric ratios are closely related to the particle size and particle distribution. In order to obtain products with a smaller particle-size difference, it is necessary to adjust the ratio of manganese and zinc ions in the reaction system.

The magnetic properties of $\mathrm{Mn}_{\mathrm{x}} \mathrm{Zn}_{1-\mathrm{x}} \mathrm{Fe}_{2} \mathrm{O}_{4}$ ferrites were studied using a vibrating-sample magnetometer at room temperature. In Figure 4, it can be observed that $\mathrm{Mn}-\mathrm{Zn}$ ferrites synthesized at different molar ratios show ferromagnetic properties because the residual saturation magnetization and coercivity are small at room temperature. The corresponding magnetic properties of $\mathrm{Mn}_{\mathrm{x}} \mathrm{Zn}_{1-\mathrm{x}} \mathrm{Fe}_{2} \mathrm{O}_{4}$ are shown in Table 1. Figure 5 shows the variation trend of the saturation magnetization (Ms) and coercivity $(\mathrm{Hc})$ with different amounts of manganese ions. It can be observed that Ms reaches the maximum value of $71.99 \mathrm{emu} / \mathrm{g}$ when the amount of manganese ions is $x=0.6$, and the coercivity curve first shows a decreasing trend and then an increase with the increase in the amount of manganese ions. When $x=0.8$, the 
coercivity is 131.84 Oe. This phenomenon shows that the saturation magnetization and coercivity of manganesezinc ferrite are closely related to the substitution degree of zinc ions for a constant external magnetic field. With the increase in the $\mathrm{Mn}^{2+}$ addition, the degree of substitution for $\mathrm{Zn}^{2+}$ increases, and the saturation magnetization of the product continues to increase. If $x>0.6$, the degree of substitution for $\mathrm{Zn}^{2+}$ gradually decreases.

With the increasing concentration of manganese ions, manganese ions preferentially occupy the octahedral B site, which results in an equal number of trivalent iron ions entering the tetrahedral A site. In the Néel model, the magnetic moment $\mu_{B}(\chi)$ can be expressed with the following Equation (2):

$$
\mu_{\mathrm{B}}(\chi)=M_{\mathrm{B}}(\chi)-M_{\mathrm{A}}(\chi)
$$

In this formula, $M_{\mathrm{A}}$ and $M_{\mathrm{B}}$ represent the magnetic moments of the tetrahedral structure position (A) and octahedral structure position (B) in the Mn-Zn ferrite, respectively. The magnetic moment $\mu_{\mathrm{B}}$ is closely related to the structure position, the distribution of metal cations and the spin/tilt effect. As the concentration of $\mathrm{Mn}^{2+}$ gradually increases, the corresponding magnetic moment $\mu_{\mathrm{B}}$ first increases and then decreases. This is because when the amount of $\mathrm{Mn}^{2+}$ is relatively small, $\mathrm{Mn}^{2+}$ can preferentially occupy position B of the octahedron structure, which forces the same amount of $\mathrm{Fe}^{3+}$ in the reaction system to enter position $\mathrm{A}$ of the tetrahedron structure. This results in a gradual increase in the superexchange force between $\mathrm{A}-\mathrm{B}$ sites, net magnetic moment and saturation magnetization Ms. When the amount of $\mathrm{Mn}^{2+}$ exceeds 0.4 , the $\mathrm{A}-\mathrm{B}$ exchange force begins to weaken, while the $\mathrm{B}-\mathrm{B}$ exchange force increases. As the content of manganese ions increases continuously and occupies the B position, the redundant part of $\mathrm{Mn}^{2+}$ enters the tetrahedron-to-tetrahedron structure position so that the same amount of $\mathrm{Fe}^{3+}$ in the tetrahedron gap returns to the octahedron structure position, resulting in an increase in the magnetic moment of the $\mathrm{B}$ position. This rearrangement rapidly increases the exchange force of the $\mathrm{B}-\mathrm{B}$ position, forcing the number of reverse parallel-spin coupling pairs in the octahedron gap to increase continuously so that the saturation-magnetization intensity is decreased. $\mu_{\mathrm{B}}$ is the experimental value of the magnetic moment of the ferrite which can be calculated with the following formula in Equation (3):

$$
\mu_{\mathrm{B}}=\frac{M \times M_{\mathrm{s}}}{5585}
$$

$\mu_{\mathrm{B}}-$ experimental value of the magnetic moment;

$M$ - molar molecular mass;

$M_{\mathrm{s}}$ - saturation magnetization.

According to Equation (3), the calculation results for $\mu_{\mathrm{B}}$ are listed in Table 1. From Table 1, it can be concluded that the values of the magnetic moment and saturation magnetization are closely related, and $\mu_{\mathrm{B}}$ is proportional to $M s$.
Figure 6 is a time-temperature curve of the $\mathrm{Mn}_{\mathrm{x}} \mathrm{Zn}_{1-\mathrm{x}} \mathrm{Fe}_{2} \mathrm{O}_{4}$ particles under a $50-\mathrm{kHz}$ external alternating magnetic field. It can be seen from Figure 6 that $\mathrm{Mn}_{\mathrm{x}} \mathrm{Zn}_{1-\mathrm{x}} \mathrm{Fe}_{2} \mathrm{O}_{4}$ can convert part of the electromagnetic energy into internal energy under the action of an external alternating magnetic field, which can increase the temperature of the product. When $x=0.2,0.4,0.6$ and 0.8 , the final temperatures can reach $(42.5,50.4$, 60.8 and 69.9) ${ }^{\circ} \mathrm{C}$, respectively. In the period of 0-200 s, the rate of the temperature rise is fast, but during the period of 200-400 s, it is slower. The temperature of the product during the period of $400-600 \mathrm{~s}$ is no longer on the increase, gradually reaching a stable value. This is because the heat production and environmental-heat dissipation of the sample are in a relative equilibrium state and the heat is no longer diffused.

The increase in the product temperature is closely related to its magnetic loss, which consists of the eddy current loss, hysteresis loss and residual loss. As the $\mathrm{Mn}-\mathrm{Zn}$ ferrite synthesized with the solvothermal method has a high resistivity, the effects of the eddy current loss and residual loss on the energy conversion can be neglected, so the final heat of the prepared product is closely related to the hysteresis loss. When the power of the applied magnetic field is fixed to a certain value, the heat generated by the hysteresis loss can be indirectly expressed by the product of the saturation magnetization, $M_{\mathrm{s}}$, and the coercivity, Hc. When $x=0.8$, the product of the saturated magnetization and coercivity reaches the maximum value, also indicating the fastest heating rate under the alternating magnetic field, and the temperature of the sample reaches the highest value. At $600 \mathrm{~s}$, the temperature can rise to $69.9{ }^{\circ} \mathrm{C}$, showing an excellent magnetocaloric effect.

\section{CONCLUSIONS}

$\mathrm{Mn}_{\mathrm{x}} \mathrm{Zn}_{1-\mathrm{x}} \mathrm{Fe}_{2} \mathrm{O}_{4}$ particles constitute a single-phase cubic spinel structure. Synthesized $\mathrm{Mn}_{\mathrm{x}} \mathrm{Zn}_{1-\mathrm{x}} \mathrm{Fe}_{2} \mathrm{O}_{4}$ particles are spherical and have good crystallinity. With an increase in the manganese ion amount, the particle size of the product first increased and then decreased. $\mathrm{Mn}_{\mathrm{x}} \mathrm{Zn}_{1-\mathrm{x}} \mathrm{Fe}_{2} \mathrm{O}_{4}$ powders show ferromagnetism. As the $\mathrm{X}$-value gradually increased, the Ms of the product first increased and then decreased. The maximum value was $71.99 \mathrm{emu} / \mathrm{g}$ at $x=0.6$. Manganese-zinc ferrites with different molar ratios lasted 600 seconds under a $50-\mathrm{kHz}$ alternating magnetic field, and the temperature of the mixed dispersion solution of the samples could reach 42.5-69.9 ${ }^{\circ} \mathrm{C}$. With an increase in the $\mathrm{x}$-value, the magnetocaloric properties of the $\mathrm{Mn}-\mathrm{Zn}$ ferrite improved significantly, which was closely related to the hysteresis-loop area and the hysteresis power loss of the product. 


\section{Acknowledgment}

This work was financially supported by National Natural Science Foundation of China (51303108) and National Equipment Pre-research Project of China $(61409230605)$.

\section{REFERENCES}

${ }^{1}$ R. P. Araújo-Neto, E. L. Silva-Freitas, J. F. Carvalho, T. R. F. Pontes, K. L. Silva, I. H. M. Damasceno, E. S. T. Egito, A. L. Dantas, M. A. Morales, A. S. Carriço, , Monodisperse sodium oleate coated magnetite high susceptibility nanoparticles for hyperthermia applications, Journal of Magnetism and Magnetic Materials, 364 (2014), 72-79, doi:10.1016/j.jmmm.2014.04.001

${ }^{2}$ V. Tsakaloudi, D. Holz, V. Zaspalis, The effect of externally applied uniaxial compressive stress on the magnetic properties of power MnZn-ferrites, J. Mater. Sci., 48 (2013), 3825-3833, doi:10.1007/ s10853-013-7183-2

${ }^{3}$ D. G. Li, C. Chen, W. Rao, W. H. Lu, Y. H. Xiong, Preparation and microwave absorption properties of polyaniline/ $\mathrm{Mn}_{0.8} \mathrm{Zn}_{0.2} \mathrm{Fe}_{2} \mathrm{O}_{4}$ nanocomposite in 2-18 GHz, J. Mater. Sci.: Mater. Electron., 25 (2014), 76-81, doi:10.1007/s10854-013-1551-1

${ }^{4}$ Q. Zhang, P. Zheng, L. Zheng, J. Zhou, H. Qin, Effect of Co-substitution on the structure and magnetic properties of $\mathrm{MnZn}$ power ferrite, J. Electroceram., 32 (2014), 230-233, doi:10.1007/s10832013-9878-9

${ }^{5}$ W. J. Wang, C. G. Zang, Q. J. Jiao, Synthesis, structure and electromagnetic properties of $\mathrm{Mn}-\mathrm{Zn}$ ferrite by sol-gel combustion technique, Journal of Magnetism and Magnetic Materials, 349 (2014), 116-120, doi:10.1016/j.jmmm.2013.08.057

${ }^{6}$ C. H. Dong, G. X. Wang, L. Shi, D. W. Guo, C. J. Jiang, D. S. Xue, Investigation of the thermal stability of $\mathrm{Mn}$ ferrite particles synthesized by a modified co-precipitation method, Science China: Physics, Mechanics \& Astronomy, 56 (2013) 3, 568-572, doi:10.1007/s11433-012-4885-4

${ }^{7}$ K. Rana, P. Thakur, M. Tomar, V. Gupta, A. Thakur, Investigation of cobalt substituted M-type barium ferrite synthesized via co-precipitation method for radar absorbing material in Ku-band (12-18 GHz), Ceramics International, 44 (2018) 6, 6370-6375, doi:10.1016/j.ceramint.2018.01.028

${ }^{8}$ T. M. Hammad, J. K. Salem, A. A. Amsha, N. K. Hejazy , Optical and magnetic characterizations of zinc substituted copper ferrite synthesized by a co-precipitation chemical method, Journal of Alloys and Compounds, 741 (2018), 123-130, doi:10.1016/j.jallcom.2018. 01.123

${ }^{9}$ V. Manikandan, X. Li, R. S. Mane, J. Chandrasekaran, Room temperature gas sensing properties of sn-substituted nickel ferrite $\left(\mathrm{NiFe}_{2} \mathrm{O}_{4}\right)$ thin film sensors prepared by chemical co-precipitation method, Journal of Electronic Materials, 47 (2018) 7, 3403-3408, doi:10.1007/s11664-018-6295-5

${ }^{10}$ M. R. Barati, Characterization and preparation of nanocrystalline $\mathrm{MgCuZn}$ ferrite powders synthesized by sol-gel auto-combustion method, J. Sol-Gel Sci. Technol., 52 (2009), 171-178, doi:10.1007/ s10971-009-2023-1

${ }^{11}$ J. L. Liu, M. Yang, S. Y. Wang, J. Q. Lv, Y.Li, M. Zhang, Sol-gel auto-combustion synthesis and properties of $\mathrm{Co}_{2} \mathrm{Z}$-type hexagonal ferrite ultrafine powders, Journal of Magnetism and Magnetic Materials, 454 (2018), 1-5, doi:10.1016/j.jmmm.2018.01.049

${ }^{12}$ N. Yasmin, I. Inam, M. Iftikhar, M. Zahid, M. N. Ashiq, S. Abdulsatar, M. Safdar, M. Mirza, Structural and magnetic properties of $\mathrm{Cr}$ doped strontium spinel ferrite $\mathrm{SrFe}_{2} \mathrm{O}_{4}$ by sol-gel auto-combustion method, Physica B: Condensed Matter, 550 (2018), 90-95, doi:10.1016/j.physb.2018.08.039

${ }^{13}$ B. H. Guan, M. H. Zahari, K. C. Lee, Effect of $\mathrm{La}^{3+}$ substitution on the structural and magnetic properties of $\mathrm{Mn}-\mathrm{Zn}$ ferrite prepared by sol-gel auto-combustion method, Materials Science Forum, 916 (2018), 91-95, doi:10.4028/www.scientific.net/MSF.916.91
${ }^{14}$ E. M. Ibrahim, The effect of sintering time and temperature on the electrical properties of MnZn ferrites, Appl. Phys. A, 89 (2007), 203-208, doi:10.1007/s00339-007-4088-4

${ }^{15}$ M. Mashadi, Y. Yunasfi, A. Mulyawan, Microwave absorption study of manganese ferrite in X-band range prepared by solid state reaction method, Jurnal Teknologi, 80 (2018) 2, 147-151, doi:10.11113/jt. v80.10773

${ }^{16}$ G. P. Kumar, V. Raghavendra, C. P. Babu, Synthesis, structural studies on Ni-Zn ferrite by solid state reaction method, Chemical Science Transactions, 5 (2016) 4, 1096-1099, doi:10.7598/cst2016. 1311

${ }^{17}$ S. Surinwong, A. Rujiwatra, Ultrasonic cavitation assisted solvothermal synthesis of superparamagnetic zinc ferrite nanoparticles, Particuology, 11 (2013), 588-593, doi:10.1016/j.partic.2012.06.008

${ }^{18}$ A. Kalam, A. G. Al-Sehemi, M. Assiri, G. Du, T. Ahmad, I. Ahmad, M. Pannipara, Modified solvothermal synthesis of cobalt ferrite $\left(\mathrm{CoFe}_{2} \mathrm{O}_{4}\right)$ magnetic nanoparticles photocatalysts for degradation of methylene blue with $\mathrm{H}_{2} \mathrm{O}_{2}$ /visible light, Results in Physics, 8 (2018), 1046-1053, doi:10.1016/j.rinp.2018.01.045

${ }^{19}$ K. Muthukumar, D. S. Lakshmi, S. D. Acharya, S. Natarajan, A. Mukherjee, H. C. Bajaj, Solvothermal synthesis of magnetic copper ferrite nano sheet and its antimicrobial studies, Materials Chemistry and Physics, 209 (2018), 172-179, doi:10.1016/j.matchemphys. 2018.02.004

${ }^{20}$ S. Thota, S. C. Kashyap, H. C. Gupta, T. K. Nath, Improved Magnetic Properties of Microwave-Processed $\mathrm{Mn}_{0.5} \mathrm{Zn}_{0.5} \mathrm{Fe}_{2} \mathrm{O}_{4}$ Nanoparticles, J. Supercond. Nov. Magn., 28 (2015), 131-136, doi: 10.1007/s10948-014-2820-9

${ }^{21}$ V. K. Sankaranarayanan, C. Sreekumar, Precursor synthesis and microwave processing of nickel ferrite nanoparticles, Current Applied Physics, 3 (2003), 205-208, doi:10.1016/S15671739(02)00202-X

${ }^{22}$ C.1 E. Patton, M. Z. Wu, K. R. Smith, V. I. Vasyuchka, Nonlinear ferrite film microwave signal processing for advanced communications-physics and devices, Ferroelectrics, 342 (2006) 1, 101-106, doi:10.1080/00150190600946260

${ }^{23}$ K. V. Sankar, S. Shanmugapriya, S. Surendran, S. C. Jun, R. K.Selvan, Facile hydrothermal synthesis of carbon-coated cobalt ferrite spherical nanoparticles as a potential negative electrode for flexible supercapattery, Journal of Colloid and Interface Science, 513 (2018), 480-488, doi:10.1016/j.jcis.2017.11.054

${ }^{24}$ M. Q. Hua, L. Xu, F. Cui, J. Lian, Y. Huang, J. Bao, J. Qiu, Y. Xu, H. $\mathrm{Xu}$, Y. Zhao, H.Li, Hexamethylenetetramine-assisted hydrothermal synthesis of octahedral nickel ferrite oxide nanocrystallines with excellent supercapacitive performance, Journal of Materials Science, 53 (2018) 10, 7621-7636, doi:10.1007/s10853-018-2052-7

${ }^{25}$ S. Y. Liu, L. Y. Wang, K. C. Chou, Synthesis of metal-doped Mn-Zn ferrite from the leaching solutions of vanadium slag using hydrothermal method, Journal of Magnetism and Magnetic Materials, 449 (2018), 49-54, doi:10.1016/j.jmmm.2017.10.001

${ }^{26}$ R. S. Melo, P. Banerjee, A. Franco, Hydrothermal synthesis of nickel doped cobalt ferrite nanoparticles: optical and magnetic properties, Journal of Materials Science: Materials in Electronics, 29 (2018), 14657-14667, doi:10.1007/s10854-018-9602-2

${ }^{27}$ T. Q. Luong, V. Nguyen, Hydrothermal synthesis of superparamagnetic zinc-nickel ferrite nanoparticles, International Journal of Materials Research, 109 (2018) 6, 555-560, doi:10.3139/146.111629

${ }^{28}$ G. S Wang, Y. Y Ma, Y. Tong, X. Dong, M. Li, Solvothermal synthesis, characterization, and magnetorheological study of zinc ferrite nanocrystal clusters, Journal of Intelligent Material Systems and Structures, 28 (2017) 17, 2331-2338, doi:10.1177/ 1045389X16685449

${ }^{29}$ W. Shen, X. Q Chen, Y. Shi, M. Shi, H. ChenSynthesis of monodisperse and single-crystal $\mathrm{Fe}_{3} \mathrm{O}_{4}$ hollow spheres by a solvothermal approach, Materials Chemistry and Physics, 132 (2012), 987-992, doi:10.1016/j.matchemphys.2011.12.046 